\title{
Molecular Characterization and Chronobiology of Hypodermosis in Cattle Slaughtered in the Diyarbakir Province of Turkey
}

\author{
Diyarbakır İlinde Mezbahada Kesilen Sığırlarda Hypodermosisin Kronobiyolojisi ve
}

Moleküler Karakterizasyonu

\author{
Duygu Neval Sayın Ipek
}

Department of Parasitology, Dicle University School of Veterinary, Diyarbakır, Turkey

\section{ABSTRACT}

Objective: The aim of present study was to investigate the chronobiology and identification of Hypoderma species in cattle slaughtered in the Diyarbakir Province of Turkey.

Methods: In total, 736 hides and subcutaneous tissue of slaughtered cattle were examined for the presence of second-and third-instar larvae in the slaughterhouse between November 2012 and May 2013. Third-instar larvae were collected from the slaughterhouses, and gDNA isolates were examined by PCR-RFLP analysis of the cytochrome c oxidase I (COI) gene of mt-DNA using Taql enzyme.

Results: In total, 62 out of 736 cattle (8.42\%) were found to be positive for Hypoderma larvae. A total of 328 (90 second- and 238 third-instar) Hypoderma larvae were detected in the hide and subcutaneous tissue of the back of infested cattle. All the 238 third-instar larvae (100\%) were identified as $\mathrm{H}$. bovis by polymerase chain reaction-restriction fragment length polymorphism (PCR-RFLP) analysis. The mean number of Hypoderma larvae in each cow was 5.29\% (62/736). In the examined cattle, second-instar larvae were observed starting from the second week of January and subcutaneous nodules were found until the last week of April.

Conclusion: $\mathrm{H}$. bovis was the dominant species detected in the Diyarbakir Province.

Keywords: Hypoderma bovis, chronobiology, PCR-RFLP, cattle, Diyarbakir

Received: 31.03 .2015

Accepted: 31.05 .2016

Öz

Amaç: Bu çalışmada Diyarbakır ilinde sığır hypodermosisine neden olan türler ve bu türlerin kronobiyolojisini araştırmak hedeflenmiş̧ir. Yöntemler: Kasım 2012-Mayıs 2013 tarihleri arasında mezbahada kesilen 736 sığııın deri ve subkutan dokuları ikinci ve üçüncü dönem larvaların varlığı yönünden muayene edilmiştir. Mezbahadan toplanan üçüncü dönem larvaların tür teşhislerini koymak için larvalardan elde edilen genomik DNA'larda (gDNA) cytochrome c oxidase I (COI) geni Restriksiyon Parçacık Uzunluk Polimorfizmi (PZR-RFLP) yöntemiyle Taql enzimi kullanılarak incelenmiştir.

Bulgular: Incelenen 736 sığıın 62'sinin $(\% 8,42)$ Hypoderma larvaları ile enfeste olduğu tespit edilmiştir. Enfekte sığırların deri ve sırt bölgesinin subkutan dokularından 328 (90 ikinci, 238 üçüncü dönem larva) adet larva toplanmıştır. Toplanan 238 (90 ikinci, 238 üçüncü dönem larva) adet üçüncü dönem larvanın PZR-RFLP ile incelenmesi sonucunda hepsinin Hypodema bovis olduğu belirlenmiştir. Hayvan başına ortalama larva sayısı 5,29 olarak hesaplanmıştır. İncelenen sığıllarda ikinci dönem larvalara Ocak ayının ikinci haftasında rastlanmaya başlanmış ve Nisan'ın son haftasına kadar subkutan nodüller tespit edilmiştir.

Sonuç: Bu çalışma ile Diyarbakır ilinde Hypoderma bovis'in yaygın bir tür olduğu moleküler olarak ortaya konulmuştur.

Anahtar kelimeler: Hypoderma bovis, kronobiyoloji, PZR-RFLP, Sığır, Diyarbakır

Geliş Tarihi: 31.03 .2015

Kabul Tarihi: 31.05.2016

\section{INTRODUCTION}

Bovine hypodermosis is a subcutaneous myiasis caused by the larvae of Hypoderma bovis (Linnaeus, 1758) and $H$. lineatum (De Villers, 1789). It is characterized by the presence of subcutaneous warbles in the dorsal and lumbar regions.
It is widely distributed in the northern hemisphere of the world. Bovine hypodermosis causes significant losses in the countries' economies because of hide damage as well as a reduction in meat and milk yields (1-3). After mature females attach their eggs on the hair of cattle, larval development on the hosts endures for approximately a year. Following

Address for Correspondence / Yazışma Adresi: Duygu Neval Sayın İpek E.mail: dnsayin@hotmail.com DOI: 10.5152/tpd.2016.4812

(C) Copyright 2016 Turkish Society for Parasitology - Available online at www.tparazitolderg.org

CTelif hakkı 2016 Türkiye Parazitoloji Derneği - Makale metnine www.tparazitolderg.org web sayfasından ulaşılabilir. 
an 8-10-month-long travel period in the deep connective tissue of the hosts, the first-instar larvae show about $15 \mathrm{~mm}$ growth. These larvae move toward the mid-dorsal area of the host. Then, the larvae molt to the second instar and increase considerably in size. It takes 30-60 days to complete this phase (4). At this stage, characteristic raised skin nodules, called warbles, are formed. The larvae make perforations in the skin of animals, through which the animals can respire. The larvae molt into the third instar, and finally, pre-pupal stage in the warble. The larvae are approximately $30 \mathrm{~mm}$ long when mature and the pre-pupa exits the warble by the breathing aperture and falls to the ground. Climatic variations influencing the period of emergence of adult flies from the pupal stage have been reported in different geographical areas of the world (1, 5-7).

Bovine hypodermosis has a wide geographical distribution (8) and is common in 55 countries. The prevalence rate in provinces of Turkey was as follows: $31.9 \%$ in Kars (9), $26.3 \%$ in Elazig (10), $22.3 \%$ in Malatya (10), 38.6\% in Sanliurfa (11), 5.3\% in Afyonkarahisar (12), 28.6\% in Erzurum (13), 3.56\% in Thracia (14), 5.08\% in Nigde (15), and $35.8 \%$ in Van (16).

In recent years, the cytochrome c oxidase I (CO1) gene of the mitochondrial DNA has been used as a target gene for a number of molecular phylogenetic and identification studies including the Hypoderma species (17). Polymerase chain reaction-restriction fragment length polymorphism (PCR-RFLP) and nucleotide sequences of fragments of the mitochondrial $\mathrm{CO} 1$ gene have provided valuable information on the identification of Hypoderma species (18). The aim of the present study was to investigate the chronobiology and identification of Hypoderma species in the Diyarbakır Province.

\section{METHODS}

\section{Study period and study area}

The study was conducted in the Diyarbakır province, located in south-eastern Anatolia, between November 2012 and May 2013. The province is located at an altitude of $670 \mathrm{~m}$ above sea level and its geographical coordinates are $37^{\circ} 55^{\prime} \mathrm{N}$ longitude and $40^{\circ} 14^{\prime} \mathrm{E}$ latitude. This city is warm and dry in the summer and $\mathrm{cool}$ in the winter. Annual average precipitation is $496 \mathrm{~mm}$, average temperature is $15.8{ }^{\circ} \mathrm{C}$, and the average humidity is $55 \%$ in the Diyarbakır Province.

Hide and subcutaneous tissue examination and larvae collection A total of 736 hides and subcutaneous tissues on the back of slaughtered cattle were examined for the presence of second$\left(L_{2}\right)$ and third-instar $\left(L_{3}\right)$ larvae in the slaughterhouse. The larvae found in the subcutaneous tissue and hides were collected, counted, and washed in physiological saline solution. They were fixed in $70 \%$ ethanol solution and larval stages were identified according to keys described by Zumpt (1). For this study, approval was obtained with 2011/19 decision number from of Experimental Animals Ethic Committee, University of Dicle on 11.05.2011.

\section{Molecular analysis}

Total genomic DNA (gDNA) was extracted from internal tissues of 238 third-instar larvae specimens with a commercial tissue DNA isolation kit (Thermo Fisher Scientific, Waltham, MA). Prior to gDNA isolation, ethanol-fixed larvae were washed five times with PBS and the internal tissues were digested overnight at 56 ${ }^{\circ} \mathrm{C}$ with 180 lysis buffer of the kit into which $20 \mu$ l Proteinase- $\mathrm{K}$ (20 $\mathrm{mg} / \mathrm{ml}$ ) was added. After digestion, the kit procedure was followed and the gDNA samples were stored at $-20^{\circ} \mathrm{C}$ until use.

The region of the mitochondrial CO1 gene was amplified by PCR using conserved specific primers previously described by Otranto et al. (18): (UEA7, 5'-TACAGTTGGAATAGACGTTGATAC-3' and UEA10, 5'-TCCAATGCACTAATCTGCCA TATTA-3') in a total volume of $50 \mu \mathrm{l}$ containing $5 \mu \mathrm{l} 10 \times$ PCR buffer, $5 \mu \mathrm{l} 25 \mathrm{mM} \mathrm{MgCl}_{2}$, $250 \mu \mathrm{M}$ each of dNTPs, $20 \mathrm{pmol}$ of each primer, $5 \mu$ l of template gDNA, and $1.25 \mathrm{U}$ of Taq DNA polymerase (Thermo Fisher Scientific, Waltham, MA). The PCR conditions were 2 min at $95^{\circ} \mathrm{C}$ (initial denaturation), 40 cycles of $1 \mathrm{~min}$ at $95^{\circ} \mathrm{C}, 1 \mathrm{~min}$ at $52^{\circ} \mathrm{C}, 1$ min at $72^{\circ} \mathrm{C}$, and finally 7 min at $72^{\circ} \mathrm{C}$ (final extension). The PCR products were separated on agarose gel (1.5\%) and stained with ethidium bromide.

Then, the PCR products were digested overnight with restriction endonuclease at $65^{\circ} \mathrm{C}$, using buffers recommended by the manufacturer in a final $36 \mu$ l volume reaction mix containing $20 \mu \mathrm{l}$ of PCR product, $1 \mu \mathrm{l} \mathrm{Taql} \mathrm{enzyme}(10 \mathrm{U} / \mu \mathrm{l}), 4 \mu \mathrm{l}$ restriction buffer, and $11 \mu \mathrm{l}$ distilled water. The restriction fragments were separated on $2 \%$ agarose gel, stained with ethidium bromide, and photographed. RFLP assays were repeated at least three times until restriction fragments were produced.

The CO1 sequences were automatically obtained using a $377 \mathrm{ABI}$ PRISM system (Applied Biosystems, Foster City, CA.). Nucleotide sequence analysis was undertaken by BLAST algorithms and databases from the National Center for Biotechnology (http://www. ncbi.nlm.nih.gov).

\section{RESULTS}

\section{Hide and subcutaneous tissue examination}

A total of $8.42 \%(62 / 736)$ examined cattle were infected with the Hypoderma larvae. In the examined hides and subcutaneous tissues, the second-instar larvae were observed starting from the second week of January and the subcutaneous nodules were found until the last week of April. A total of 328 larvae of $\mathrm{H}$. bovis were collected from the slaughterhouse. 90 of them were classified as L2 and 238 of them were classified as L3. The highest prevalence of infestation (23\%) occurred in March. H. bovis larvae were not found in November and December of 2012 and May of 2013. The mean number of larvae per cattle was 5.29 (Table 1).

\section{Molecular findings}

In total, 238 gDNA isolates were examined by PCR-RFLP analysis of the CO1 region of mt-DNA using restriction endonuclease (Taql). $668 \mathrm{bp}$ amplicons in the mitochondrial $\mathrm{COI}$ gene regions were obtained from all isolates by PCR (Figure 1a). After digestion of the PCR products with the Taql restriction enzyme, 432 and 256 bp bands in 236 samples and 432, 164, and 92 bp bands in two samples were obtained. RFLP patterns of isolates are presented in Figure 1b. All sequences obtained were $99 \%$ similar to the $H$. bovis sequence in the GenBank ${ }^{\mathrm{TM}}$ (Accession number AF497761). Analysis of the sequences demonstrated that different RFLP bands obtained originated from intraspecific polymorphism. 
Table 1. Monthly prevalence and mean larval burden of hide examination in cattle slaughtered in the Diyarbakır Province

\begin{tabular}{|c|c|c|c|c|c|c|}
\hline Months & $\begin{array}{c}\text { Examined } \\
\text { animals }\end{array}$ & $\begin{array}{r}\text { Infested } \\
\text { animals }\end{array}$ & $\begin{array}{c}\text { Infestation } \\
(\%)\end{array}$ & $\begin{array}{c}\text { Number of } \\
\text { larvae }\end{array}$ & $\begin{array}{l}\text { Larvae } \\
\text { per animal }\end{array}$ & $\begin{array}{l}\text { H. bovis } \\
\text { L2 L3 }\end{array}$ \\
\hline November & 84 & 0 & 0 & 0 & 0 & 0 \\
\hline December & 98 & 0 & 0 & 0 & 0 & 0 \\
\hline January & 122 & 7 & 5.73 & 16 & 2.28 & 142 \\
\hline February & 103 & 13 & 12.62 & 153 & 11.76 & 5697 \\
\hline March & 113 & 26 & 23 & 104 & 4 & 2084 \\
\hline April & 92 & 16 & 17.39 & 55 & 3.43 & $0 \quad 55$ \\
\hline May & 124 & 0 & 0 & 0 & 0 & 0 \\
\hline Total & 736 & 62 & 8.42 & 328 & 5.29 & $90 \quad 238$ \\
\hline
\end{tabular}
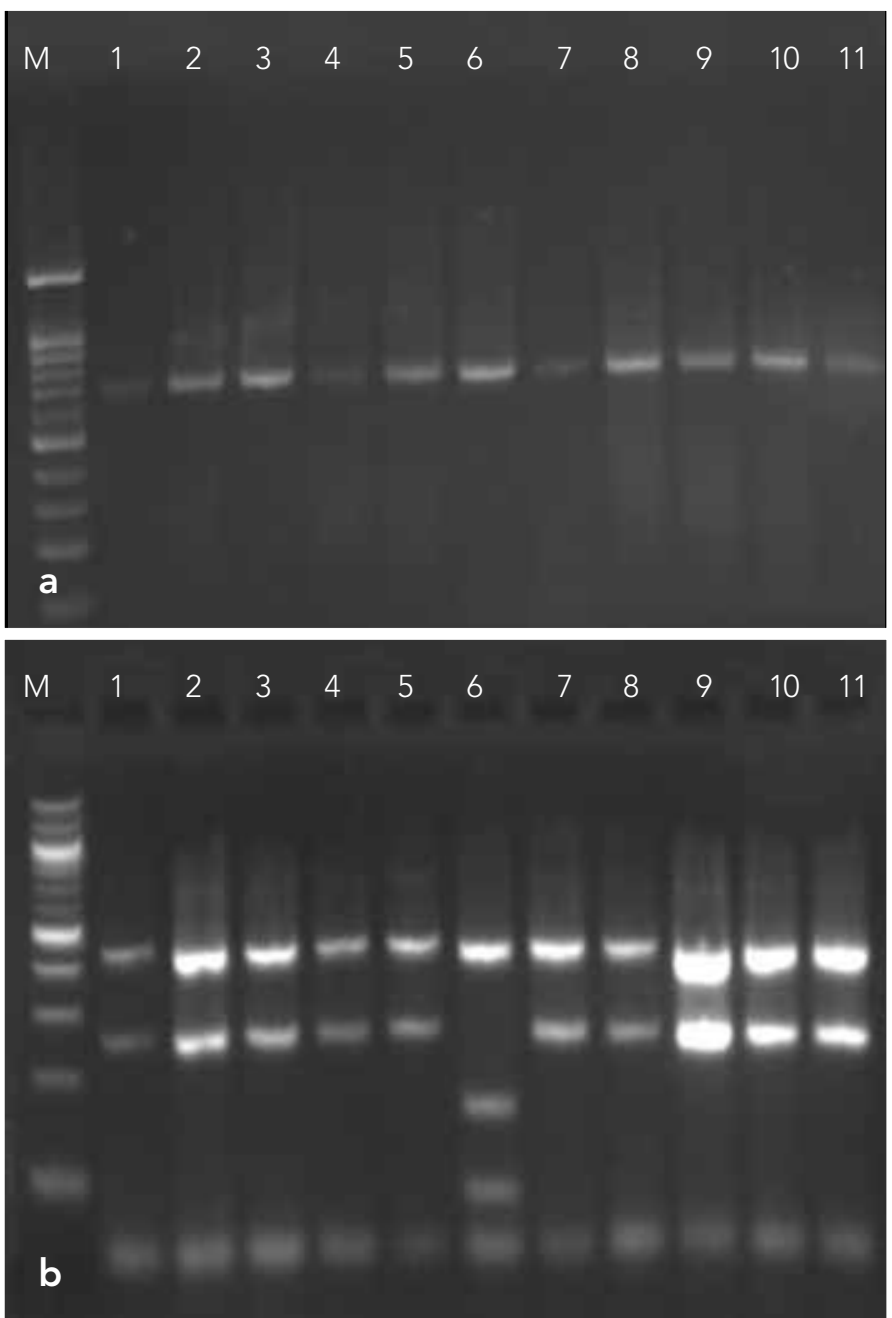

Figure 1. a, b. (a) PCR amplification of mitochondrial CO1 genes of Hypoderma species. M: Marker (100 bp); 1-11: hypoderma bovis (688 bp). (b) CO1-PCR products digested with Taql enzyme. M: DNA marker (100 bp); 1-11: hypoderma bovis isolates. (sample 6 revealed different band profiles)

\section{DISCUSSION}

Hypodermosis is an important veterinary problem because of its worldwide prevalence and significant economic losses. Economic losses are due to decreasing of productivity potential and leather quality. The disease is caused by two parasitic fly species in cattle, $H$. bovis and $H$. lineatum. In this study, the infestation rate was found to be $8.42 \%$ in cattle slaughtered in the abattoirs of Diyarbakir. The prevalence of hypodermosis was lower than the results obtained by the studies conducted in Erzurum 28.6\% (13), Kars 31.9\% (9), Şanlıurfa $38.6 \%$ (11), and Van $35.85 \%$ (16). The prevalence of Hypoderma spp. larvae (8.42\%) in this study was higher than the findings in Thrace (3.56\%) (14), Niğde (5.08\%) (15), and istanbul (1.9\%) (19).

The biological characteristics of the Hypoderma species differ from country to country and from region to region taking into account seasonal conditions. Therefore, to determine the most suitable time for the treatment of cattle with systemic insecticides, it is necessary to put forth the distribution of the dominant fly species and the months when large numbers of first-instar larvae in the esophagus or in the vertebral canal appears $(1,20,21)$.

For the differential diagnosis of species, morphological features can be used. However, as the differential diagnosis of the third-instar larvae on the basis of morphological characteristics is difficult to perform, recently, molecular differentiation method seem to be more useful for species identification. Some studies have evaluated whether the differential diagnosis between these two species is possible with PCR-RFLP. These studies reported that the differential diagnosis between $\mathrm{H}$. bovis and $\mathrm{H}$. lineatum is possible with Taql restriction enzyme analysis $(13,15,22)$. We also used this restriction enzyme (Tagl) with PCR-RFLP. Otranta et al. (18) reported that, after the digestion of the PCR product with the restriction enzyme Taql, the RFLP profile obtained from $\mathrm{H}$. bovis revealed two fragments whereas H. lineatum was not digested. Simsek et al. (13) reported 438 and 250 bp bands for $\mathrm{H}$. bovis and 488 and $200 \mathrm{bp}$ bands for $\mathrm{H}$. lineatum with the same enzyme using PCR-RFLP. Oğuz (22) conducted a similar study and reported that, after the digestion with the same enzyme, they observed the bands $288 \mathrm{bp}$ and $400 \mathrm{bp}$ for $\mathrm{H}$. lineatum and the 
bands $250 \mathrm{bp}$ and $438 \mathrm{bp}$ for $\mathrm{H}$. bovis. In our study, after the digestion of PCR products with the Taql restriction enzyme, we obtained two bands of approx. 432 and $256 \mathrm{bp}$ in 236 samples and three bands containing 432, 164, and 92 bp in two samples. The results of sample sequence analysis showed that all samples revealed two different band profiles and were identified to be $\mathrm{H}$. bovis. The analysis of the sequential results also revealed that there are intraspecific differences among the samples, as seen from the different profiles. In two samples, given the three band profiles, T nucleotide was replaced with $\mathrm{C}$ nucleotide on the 597 alignment position. The emerging nucleotide difference constitutes a digestion zone for the Taq1 enzyme. It is observed that Taq1 digestion enzyme, which seems to be useable in the differential diagnosis of species, may cause false results because of the intraspecific differences.

Because the animal owners did not give permission for the inspection of the carcass, L1 of $\mathrm{H}$. bovis could not be obtained from the cattle that were slaughtered in the abattoir. But it was possible to collect L2 and L3 under the skin of infested animals. Consequently, the obtained findings of $L 2$ and $L 3$ enables the determination of the time they had spent in the cattle. Studies conducted in Europe showed the $\mathrm{L} 2$ and $\mathrm{L} 3$ of $\mathrm{H}$. bovis were seen between December and May in Mediterranean areas, between May and June in Northern and Central parts, and between March and June in the Eastern parts of Europe (6). Karatepe and Karatepe (15) reported that L2 and L3 were seen starting in March and found until April, and the most suitable time for treating cattle with hypodermosis in Nigde province was between 15 October to 15 November. Based on these results, it was understood that $H$. bovis larvae reached $L 2$ in the middle of January and L3 in February. An increase in the number of L2 and L3 was observed under the back skin of the cattle in February. So, it may mean that all the first-instar larvae that were moving in the cattle tissue turn into second-instar larvae between middle October-November, and they completely reached under the skin in middle January-March. Then, all the second-instar larvae that were under the skin would mostly turn into third-instar larvae in February and March. In April, the number of third-instar larvae that were under the skin decreased and in the following months no larvae could be seen in cattle.

\section{CONCLUSION}

Determination of the dominant species in the region and the most suitable time for treating cattle is important with regard to the possible eradication or prevention/control programs planned for implementation in the region.

Ethics Committee Approval: Ethics committee approval was received for this study.

Informed Consent: N/A.

Peer-review: Externally peer-reviewed.

Conflict of Interest: No conflict of interest was declared by the authors.

Financial Disclosure: The authors declared that this study has received no financial support.

Etik Komite Onayı: Bu çalışma için etik komite onayı alınmıştır. Hasta Onamı: N/A

Hakem Değerlendirmesi: Dış bağımsız.
Çıkar Çatışması: Yazarlar çıkar çatışması bildirmemişlerdir.

Finansal Destek: Yazarlar bu çalışma için finansal destek almadığını belirtmiştir. REFERENCES

1. Zumpt F. Myiasis in man and animals in the old world. London: Butterwoths; 1965. p. 267.

2. Colwell DD. Cattle Grubs Biology and Control. Branch, Agri. Publ. 1880/E, Canada: Ottawa; 1992.p. 6-17.

3. Boulard C. Durably controlling bovine hypodermosis. Vet Res 2002; 33: 455-64. [CrossRef]

4. Scholl PJ. Biology and control of cattle grubs. Annu Rev Entomol 1993; 39: 53-70. [CrossRef]

5. Navarrete I, Reina D, Hernadez-Rodriguez S, Martinez-Moreno FJ, Galeano C. Preliminary studies on bovine hypodermosis in the province of Caceres (Spain). Proc. of symposium on the control methods for warble fly in cattle and goats; Sept. 16-18; Brussels: 1993. p. 3-11.

6. Reina D, Martinez-Moreno FJ, Navarraete I. Studies with the rearing of cattle warble flies in Estremadura, Spain. In: Improvements in control methods for warble flies in farms livestock. Proc. XII European COST 811; Kinsale, Ireland; 1995.

7. Khan MR, Ahmed H, Panadero-fontan R, Sandez CL, Farooq M, Naqvi SMS, Qayyum M. Risk mapping of bovine hypodermosis by using Geographical Information System (GIS) in cattle of subtropical region, Pakistan. J Infect Dev Ctries 2015; 9: 872-7. [CrossRef]

8. Ahmed H, Khan M R, Panadero-fontan R, Sandez C L, Farooq M, Naqvi SMS, Qayyum M. Geographical distribution of hypodermosis (Hypoderma sp.) in Northern Punjab, Pakistan. Kafkas Univ Vet Fak Derg 2012; 18 (A): 215-9.

9. Kara M, Arslan MO, Gicik Y. The prevalence of bovine hypodermosis in Kars province, Turkey. Trop Anim Health Prod 2005; 37: 617-22. [CrossRef]

10. Simsek S, Utuk AE, Koroglu E, Dumanli N. Seroprevalence of hypodermosis in cattle in some provinces of Turkey. Res Vet Sci 2008; 84: 246-9. [CrossRef]

11. Ozkutlu Z, Sevgili M. Seroprevalence of hypodermosis in cattle in the province of Sanliurfa. Türkiye Parazitol Derg 2005; 29: 275-9.

12. Cicek H, Cicek H, Eser H, Tandoğan M, Sarımehmetoğlu HO. Prevalence and economic significance of bovine hypodermosis in Afyonkarahisar province of Turkey. Trop Anim Health Prod 2011; 43: 17-20. [CrossRef]

13. Balkaya I, Simsek S, Saki CE. A serological and molecular survey of cattle hypodermosis in east-Turkey. Vet Parasitol 2010; 173: 287-91. [CrossRef]

14. Sayın F, Kalkan A, Karaer Z. Türkiye'de Sığır Hypodermosis'i Üzerine Epidemiyolojik Araştırmalar. F Ü Sağlık Bil Dergisi 2000; 14: 115-27.

15. Karatepe M, Karatepe B. Hypodermosis in cattle slaughtered in Nigde province, Turkey. Trop Anim Health Prod 2008; 40: 383-6. [CrossRef]

16. Özdal N, Değer S. Van Belediye Mezbahasında kesilen sığır, koyun ve keçilerde Hypodermosis. YYÜ Vet Fak Derg 2005; 16: 23-5.

17. Li W, Ano H, Jin J, Nasu T, Ma Y, Zhu X, et al. Cytochrome oxidase I gene sequence of Hypoderma sinense infecting yaks in the Qinghai-Tibet high plateau of China. Vet Parasitol 2004; 124: 131-5. [CrossRef]

18. Otranto D, Traversa D, Tarsitano E, Stevens J. Molecular differentiation of Hypoderma bovis and Hypoderma lineatum (Diptera, Oestridae) by polymerase chain reaction-restriction fragment length polyrnorphism (PCR-RFLP). Vet Parasitol 2003; 12: 197-201. [CrossRef]

19. Gulanber A, Tuzer E, Gargili A, Toparlak M, Efil I, Keles V, et al. A survey of hypodermosis in cattle slaughtered in Thrace (Trakya) Turkey, Turk J Vet Anim Sci 2000; 24: 429-30.

20. Soulsby EJL. Helminths, Arthropods and Protozoa of Domesticated Animals, 7th. Ed. The English Language Book Society and Bailliere Tindal, London, 1982. p. 432-7.

21. Kettle DS. Medical and Veterinary Entomology. CAB International: Wallingford. Oxon, UK. 1990. p. 267-73.

22. Oğuz B. Cytochrome Oxidase I Gene sequences that cause Hypodermosis cattle species by PCR-RFLP technique investigation. Türkiye Parazitol Derg 2013; 37: 190-4. [CrossRef] 